\title{
Best Practices In Physics Teacher Education In Selected ASEAN Countries
}

\author{
Ida Kaniawati \\ Department of Physics Education \\ Universitas Pendidikan Indonesia \\ Bandung, Indonesia \\ kaniawati@upi.edu
}

\begin{abstract}
This study aims to increase the collaboration on quality educational research projects in different countries in the ASEAN region; and identify best practices in pedagogy and assessment in physics teacher education in selected country which are Indonesia, Philippine, Cambodia and Thailand. The study will be conducted for three years long and projected to: 1) Investigate curriculum guiding principles in the different countries, 2) Investigate course design in terms of focus on content and pedagogy subjects, 3) Identify focus in education subjects in terms of techniques and theories of teaching and learning that they promote, 4) Develop case studies of best practices classes in teaching and/or alternative assessment as nominated by the research group from the different institutions and conduct class observations in each, and 5) Investigate students views about their experiences in these classes. Particularly, the study in Indonesia will be conducted in UPI involving Physics Education Department. The data will be collected by qualitative method underpinned instruments developed by the research team
\end{abstract}

\section{INTRODUCTION}

The ASEAN Leaders adopted the Declaration of ASEAN Concord II to establish an ASEAN community by 2020. The ASEAN Community was established comprising three pillars, namely political and security community, economic community, and socio-cultural community that are closely intertwined and mutually reinforcing for the purpose of ensuring durable peace, stability, and share prosperity in the region.

Education plays an important role in the socio cultural community. The strategic mission of the community includes the promotion of education networking in various levels of educational institutions and the enhancement and support "student and staff exchanges and professional interaction include creating research clusters among ASEAN institutions of higher learning, in close collaboration with the Southeast Asia Ministers of Education Organization (SEAMEO) and the ASEAN University Network". The document identifies special focus on the promotion of equal access to education for women and girls and enhancing the exchange of best practice on gender-sensitive school curriculum. Likewise, it identifies poverty alleviation as a particular challenge that the ASEAN community should priorities including the role of education in such endeavor.
Research from around the world demonstrates that quality teaching matters. Study compared the performance of students in three schools in the USA that adapted to "implement a comprehensive set of instructional, teacher support, and school climate reforms (embedded in the Talent Development Middle School [TDMS] reform model)". In comparison, they " had significantly greater numbers of students close their mathematics achievement gaps than did the other 23 middle schools in the district also serving highpoverty and high minority student bodies" [2].

In this context we raise the question what is "quality" teaching. Atweh [1] stated that several frameworks, based on different theoretical underpinnings, exist in the literature that may be useful to assist in the development of a variety of teaching techniques that cater for a wide diversity of students. Perhaps widely known such frameworks are those of Blooms' Taxonomy [3], Gardner's Multiple Intelligences [6], de Bono's Thinking Hats [5] and Myer-Briggs Personality Types [5].

A promising and comprehensive framework developed recently in the state of Queensland in Australia, called Productive Pedagogy is an example of an attempt to integrate research findings on effective teaching from a variety of areas of research within education itself.

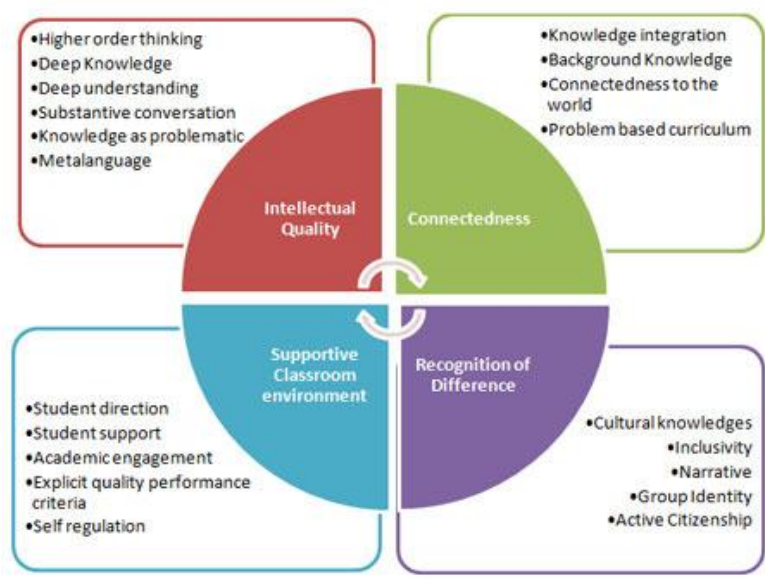

Fig.1. Dimensions of Productive Pedagogies 
The productive pedagogy framework identifies four main essential characteristics of 'good' teaching (Figure 1):

- Intellectual Quality

- Connectedness

- Supportive Classroom environment, and

- Recognition of difference

Within each of these dimensions, the framework identifies a range of elements that elaborate the dimensions. In this study, the Productive Pedagogy will be used to identify and report on aspects of the best practice identified by the different researchers within their contexts.

The project plan include the formation of a collaborative network of 2-3 researchers from each of leading teacher education institutions in five countries in the ASEAN region (at this stage, we are targeting Indonesia, Vietnam, Cambodia, Malaysia and Philippine). The researchers will develop case studies of best practices in teaching and assessment in their initial teacher education courses using the Productive Pedagogy framework as a guide.

1. The project constitutes a tangible collaboration between researchers in different ASEAN countries that share similar challenges in terms of development through education, prevalence of poverty, student achievement and traditional teaching methods. It leads into collaboration in data collection, analysis and reporting. Similarly, it contributes to another project supported by PNU Innovation in Pedagogy and Assessment Project (IPAP) which is the subject of another proposal under this scheme.

2. The role of quality teaching and quality teacher has been recognized internationally. The most effective means to develop numeracy with young children are quality teachers. An education system cannot exceed the quality of its teachers. While quality teaching benefits all students, evidence shows that it benefits low-achieving students more, thus it contributes to narrowing the gap between different groups of students. At teacher education courses, prospective teachers have a chance to experience alternative means of teaching and assessment that lays the foundation to their practices in the future.

3. This is not a comparison study on teaching and assessment of mathematics and science between the different countries. We believe that identifying good practices within each of the countries would provides a range of evidence based practices that may be utilized by other institutions and subjects rather in a reflective way rather than simply transplant practices from one context to another.

4. The International Collaborative Researchers scheme at PNU identifies "comparative studies between the teaching practices in the Philippines and those in neighboring countries as one of its agenda items. Similarly, it identifies the aim of developing standards in teacher education curriculum as another agenda item. While this project does not aim to achieve such standards, the results undoubtedly can contribute towards such agenda in the future.

The project aims to Increase the collaboration on quality educational research projects in different countries in the ASEAN region; and identify best practices in pedagogy and assessment in mathematics and science teacher education. In particular (Figure 2):

1. Examination of curriculum guiding principles in the different countries

2. Course design in terms of focus on content and pedagogy subjects

3. Identify focus in education subjects in terms of techniques and theories of teaching and learning that they promote

4. Develop case studies of best practices classes in teaching and/or alternative assessment as nominated by the research group from the different institutions and conduct class observations in each.

5. Investigate students views about their experiences in these classes.

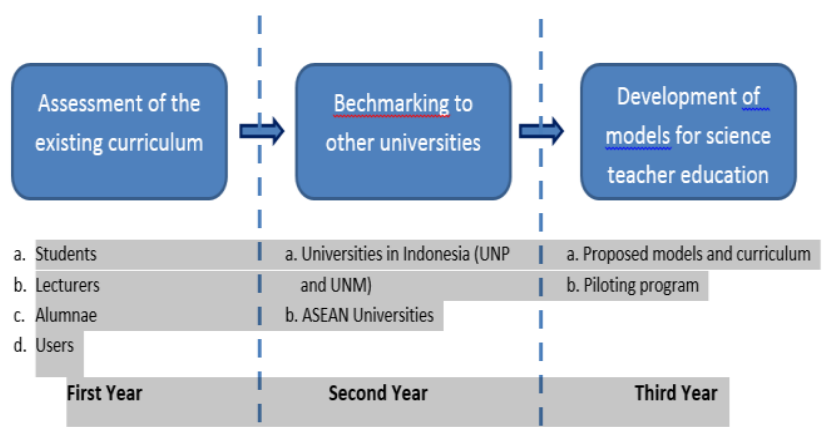

Fig.2. Research Roadmap

The different dimensions of productive pedagogies will be used in the selection of the classes identified as best practice, in observations of classes and in discussion with the teachers in them after the observations.

\section{METHODOLOGY}

The method used is a qualitative method. Subjects were 4 educational courses, 4 physics subject content and one school physics course. Respondents are professors, students, and alumni of the chairman of the study program Physical Education courses. The instrument used was a questionnaire for lecturers, head of the study program, students and alumni. Data were analyzed using descriptive analysis.

\section{RESULT AND DISCUSSION}

Based on the results of questionnaire analysis student of physical education, can be seen in Figure 3 . 


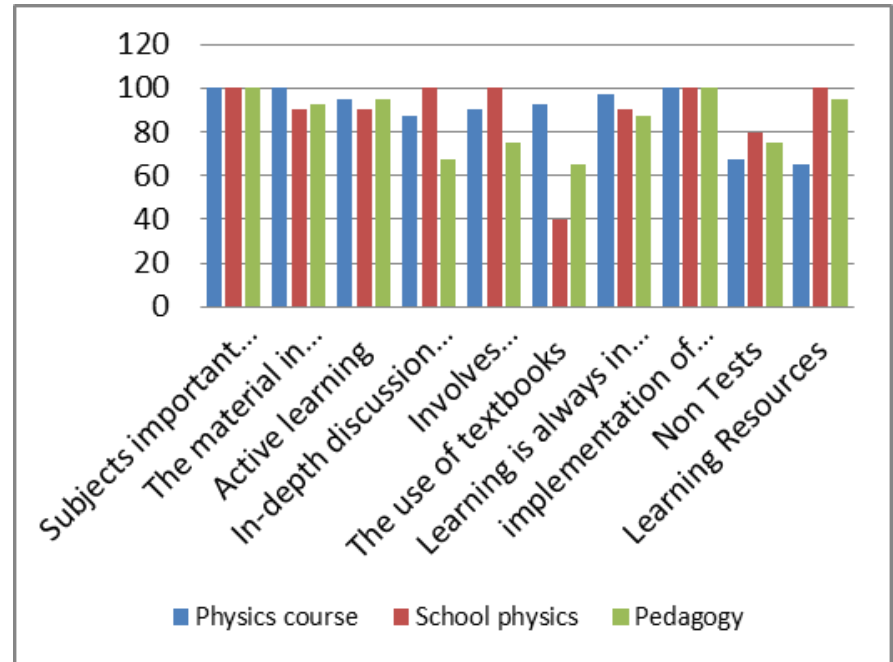

Fig.3. Student Response Based on Classification Courses

Based on figure 3, findings from the student questionnaire:

1. In general Subjects were given important for a job as a teacher

2. Material according Syllabus, active learning, discussed the matter in depth, using an evaluation test (UTS and UAS)

3. Average student answered in the bottom $80 \%$ is the lack of use of text books $(74 \%)$ and the use of non-test assessment $(72 \%)$

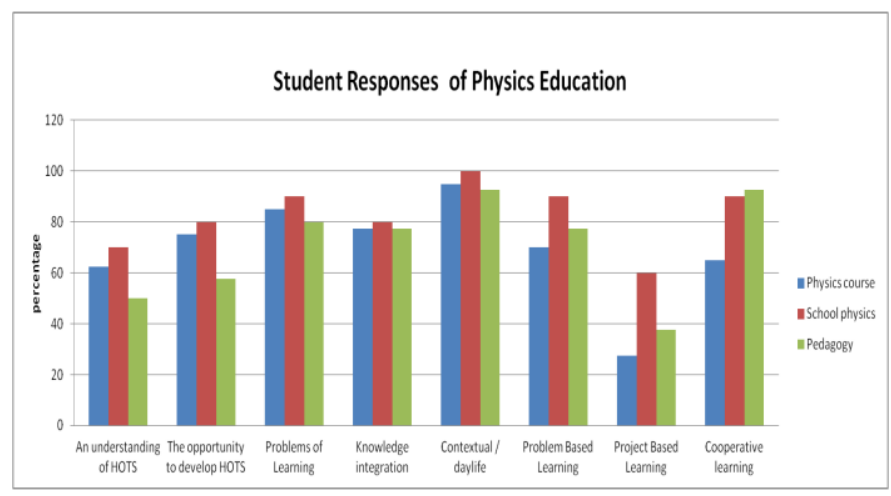

Fig.4. Student Responses of Physics Education

Based on Figure 4, student responses are:

1. Above $80 \%$ of the students found: linked materials on learning at school, daily life, learning with cooperative learning

2. About $58 \%$ of the students understand about HOTS

3. $63 \%$ of the students stated given the opportunity to develop HOTS

4. $73 \%$ found the average course integrating knowledge

5. $76 \%$ found the average course do problem-based learning

6. $36 \%$ found the average course doing project-based learning

Student feedback on the course of physics can be seen at Table 1.
TABLE I. Student feedback on the course of physics

\begin{tabular}{|l|l|}
\hline \multicolumn{1}{|c|}{ Aspec } & \multicolumn{1}{c|}{ Student Answer } \\
\hline Material Class & $\begin{array}{l}\text { Should be more in-depth, daily life, there } \\
\text { is the application of concepts, focusing on } \\
\text { the material to be tested and exercises }\end{array}$ \\
\hline $\begin{array}{l}\text { Learning } \\
\text { methods }\end{array}$ & $\begin{array}{l}\text { Interactions of faculty and students, } \\
\text { organized demonstrations, cooperative } \\
\text { learning, problem solving, presentations, } \\
\text { discussions, simulations, demonstrations }\end{array}$ \\
\hline $\begin{array}{l}\text { Instructional } \\
\text { Media }\end{array}$ & $\begin{array}{l}\text { Media teaching / phenomenon, } \\
\text { demonstration tool, video, animation, } \\
\text { media more varied, more creative the } \\
\text { required media, the media in the } \\
\text { laboratory }\end{array}$ \\
\hline $\begin{array}{l}\text { Evaluation of } \\
\text { learning }\end{array}$ & $\begin{array}{l}\text { Transparency value, test the unit should } \\
\text { be 4 times, given quizzes, given the non- } \\
\text { test evaluation, needs assessment attitude } \\
\text { or project assessment, should questions } \\
\text { given in the form of concept application, } \\
\text { each task should be given feedback }\end{array}$ \\
\hline
\end{tabular}

Student feedback on the course of School physics can be seen at table 2 .

TABLE II. Student feedback on the course of School physics

\begin{tabular}{|l|l|}
\hline \multicolumn{1}{|c|}{ Aspec } & \multicolumn{1}{c|}{ Student Answer } \\
\hline Material Class & $\begin{array}{l}\text { Should present the facts, given the prior } \\
\text { knowledge about the basic competence } \\
\text { analysis, chose the verb operational. }\end{array}$ \\
\hline $\begin{array}{l}\text { Learning } \\
\text { methods }\end{array}$ & $\begin{array}{l}\text { Should be done problem-based learning, } \\
\text { project }\end{array}$ \\
\hline $\begin{array}{l}\text { Instructional } \\
\text { Media }\end{array}$ & $\begin{array}{l}\text { Media should not only use power point, } \\
\text { need to be set of books used, used props }\end{array}$ \\
\hline $\begin{array}{l}\text { Evaluation of } \\
\text { learning }\end{array}$ & $\begin{array}{l}\text { Should be given the points that should } \\
\text { exist in a book compiled by the student, a } \\
\text { more detailed evaluation }\end{array}$ \\
\hline
\end{tabular}

Feedback from the students to the course of physics pedagogy can be seen at Table 3 .

Questionnaire results of Alumni:

Length of study average: 6.1 yrs, Average GPA: 2.94, Wait time to get a job: 2.3 months.

The results of questionnaire analysis from Alumni:

- English language ability required 30\%, 40\% said less necessary

- ICT 70\% is needed

- Terms GPA of 2.75 as much as $40 \%$, does not require a GPA of $50 \%$

- The knowledge and skills to follow the development of science and technology: yes. $90 \%$

- After graduating relationship with department $50 \%$ 
- How: a visit to the office of the department of $50 \%, 20 \%$ website

- In order to legalize $80 \%, 20 \%$ alumni meeting, looking for a job $10 \%$

- Contributions: scholarships to students (10\%)

TABLE III. Feedback from the students to the course of physics pedagogy

\begin{tabular}{|l|l|}
\hline \multicolumn{1}{|c|}{ Aspec } & \multicolumn{1}{c|}{ Student Answer } \\
\hline $\begin{array}{l}\text { Material } \\
\text { Class }\end{array}$ & $\begin{array}{l}\text { Material deepened, connected with the } \\
\text { phenomenon, choose material that needs to } \\
\text { be delivered in the lecture, the material made } \\
\text { uniform for all classes, deepened material } \\
\text { about the making of instruments, media } \\
\text { types other learning, necessary discussion } \\
\text { web blog even deeper Should propagated } \\
\text { material on the curriculum in 2013, the } \\
\text { material is more structured, more detailed, } \\
\text { focused on learning appropriate models for } \\
\text { physics, materials deepened to learning in } \\
\text { the classroom setting. }\end{array}$ \\
\hline $\begin{array}{l}\text { Learning } \\
\text { methods }\end{array}$ & $\begin{array}{l}\text { More varied, multiply method of discussion, } \\
\text { conducted project-based learning, the value } \\
\text { of data processing is done directly }\end{array}$ \\
\hline $\begin{array}{l}\text { Instructional } \\
\text { Media }\end{array}$ & $\begin{array}{l}\text { Added media more attractive, video, written } \\
\text { other books, journals }\end{array}$ \\
\hline $\begin{array}{l}\text { Evaluation } \\
\text { of learning }\end{array}$ & $\begin{array}{l}\text { Rating discussion highlighted, more } \\
\text { transparent, Evaluation adapted to the } \\
\text { material presented in each class, the duration } \\
\text { of time when UAS extended again, test } \\
\text { questions should be different for each class, } \\
\text { the evaluation method agreed from the start }\end{array}$ \\
\hline
\end{tabular}

Opinion of the alumni of the abilities that is relevant to the needs of the job can be seen at Table 4 .

TABLE IV. The abilities relevant to the job

\begin{tabular}{|l|l|l|}
\hline \multicolumn{1}{|c|}{ Attitudes } & \multicolumn{1}{c|}{ Knowledge } & \multicolumn{1}{c|}{ Skills } \\
\hline • Politeness & • science and & • English \\
- Honest, & technology- & - IT \\
responsibility & based IMTAQ & •Designing \\
- Patience & - Knowledge of & practicum \\
- Socialize & the department & - Ability to teach \\
• Proud of the & of physics and & fun \\
physical & other & - Working in \\
education & Misconception & the Lab with \\
department & in materials & local materials \\
- Proud to work & physics & - Mastery of \\
- Social & Development of & multimedia \\
competence and & teaching & \\
personality & materials & \\
- Discipline & manufacture & \\
\hline
\end{tabular}

TABLE IV. Cont'

\begin{tabular}{|c|c|c|}
\hline Attitudes & Knowledge & Skills \\
\hline $\begin{array}{l}\text { - Do not give up } \\
\text { easily, } \\
\text { - adjust to the } \\
\text { environment }\end{array}$ & $\begin{array}{l}\text { - Knowledge of } \\
\text { teaching } \\
\text { - Style of learners } \\
\text { - Classroom } \\
\text { action research } \\
\text { - The } \\
\text { development of } \\
\text { technology today }\end{array}$ & \\
\hline
\end{tabular}

The ability of the perceived weak:

- Ability ICT

- Making props / learning media

- Classroom management

- Ability learning innovations

- Ability to interact and confidence lacking

\section{CONCLUSION}

1. Briefing prospective teachers strongly influenced how the curriculum is formed

2. The learning process in favor of increasing the ability of HOTS

3. The formation of character prospective teachers to become professional teachers starting from his professor role model

4. The assessment is an important aspect in knowing the ability of prospective teachers to demonstrate their professional ability

\section{REFERENCES}

[1] Atweh, B. (2007). What is this thing called Social Justice and what does it have to do with Us in the Context of Globalization The Philosophy of Mathematics Education Journal, 21.

[2] Balfanz, R., \& Byrnes, V. (2006). Closing the mathematics achievement gap in high-poverty middle schools: Enablers and constraints. Journal of Education for Students Placed at Risk (JESPAR), 11(2), 143-159. The study is ineligible for review because it does not include an outcome within a domain specified in the protocol.

[3] Bloom B S (ed.) (1956) Taxonomy of Educational Objectives, the classification of educational goals Handbook I: Cognitive Domain New York: McKay

[4] Briggs Myers , I., \& Briggs, K.C. (1985). Myers -Briggs Type Indicator (MBTI) . Palo Alto, CA: Consulting Psychologists Press.Ca 
[5] De Bono, E. (1985). Six Thinking Hats: An Essential Approach to Business Management. New York, NY: Little, Brown, \& Company.

[6] Gardner, H. (2000). The disciplined mind. New York: Simon and Schuster. 